\title{
Status and Analysis of Informationized Quality Supervision of Higher Education in China
}

\author{
WU Yun-na, HU Zi-shan ${ }^{\mathrm{a}}$, YANG Yi-sheng, WANG Qing and ZHANG Jin-ying \\ School of Economics and Management \\ North China Electric Power University \\ Beijing, P. R. China

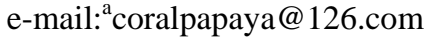

\begin{abstract}
In recent years, with the rapid development of information technology, the quality of higher education regulatory practices will stand more chances to combine with information technology platform. Exploration to the supervision system on the higher education quality in China is the inevitable requirement to promote the healthy development of Chinese higher education, and how to combine the higher education quality supervision practices with information technology has become an innovative topic in theory and technology researches. This paper describes the government's concern about the quality of higher education as well as the information process of higher education management, and proposes recommendations about the establishment of a coordinated information supervision platform of higher education quality through the analysis of problems that exist during the information construction process.
\end{abstract}

Keywords-higher education ; quality supervision ; information platform

\section{INTRODUCTION}

February 13, 1993, the CPC Central Committee and the State Council officially issued National Education Reform and Development Program, proposed eight basic principles of building socialism education system with Chinese characteristics, indicating that education is the foundation of the socialist modernization, the government must adhere to place education the strategic position in priority to development. Since 1949, the higher education has made remarkable achievements with the support of the government and the hard work of educators. However, the government and society have been increasingly worried about the quality of higher education with the expansion of college enrollment, and how to improve the quality of education has become an urgent problem to be solved. However, there still no comprehensive management and control system of higher education quality established from the point of view of supervision and management.

With the development of the Internet, informationized higher education management has brought a profound impact on the supervision and management to the higher education quality. The network has not only become essential to the scientific research, but also important means of higher education management. Clearly put forward by the Ministry of Education on February 10, 2004 in Education Revitalization Action Plan 2003-2007, the informatization projects of education are aimed at accelerating the construction of information technology infrastructure and comprehensively improving the application level of information technology in education system. At the same time, it is how to design and implement effective information management mode that an important issue the government and universities facing to improve the effectiveness of education quality supervision.

\section{STATUS OF INFORMATIONIZED QUALITY} SUPERVISION OF HIGHER EDUCATION IN CHINA

The informationized education services and supervision has been playing an increasingly significant role to improve the education efficiency, ameliorate the service functions, and expand the publicity participation. The establishment of educational service and supervision information system could provide information security for government's work, and has great significance for strengthening education services and supervision in China, as well as promoting the innovative transformation of government's function and management.

\section{A. Government}

Chinese government has attached great importance to the higher education quality management. Introduced by the Ministry of Education on March 16, 2012, the document Opinions to Comprehensively Improve the Quality of Higher Education introduced to construct the education evaluation system, which is college self-assessment based, normal teaching data monitored, professional certification and international assessment concerned, and government, universities, specialized agencies and social pluralism evaluation combined. This document also put forward the construction of academic degree and graduate education quality monitoring information platform. It showed that the government would pay more attention to strengthen the construction of the supervision information platform of higher education. The construction work of higher education supervision information platform has got the main chance and the contribution of the research for the higher education also shows its great potential to develop.

The web portal of the Ministry of Education is a typical supervision information platform of education. This web is equipped with columns Service Window, Service Hall, and Interactive Platform. Through the portal, the society can browse the education policies, the work of the Ministry of 
Education, as well as the relevant policies' interpretation. Education Review shows objective analysis and commentary on popular topics of education; Lighthouse informs criticism to illegal events and schools; Query Wizard can link to the website of Higher Education Evaluation Center, where the universities' education evaluation dynamic and the reports of the education quality shown. What's more, before the implementation of relevant policies and regulations, the Ministry of Education would ask the society for comments through the website.

The Chinese Ministry of Education has shown the society the supervision forces that the government and the media have had towards education, through this open, transparent platform. However, as the portal of the Ministry of Education, this website pays attention to the integrally education condition in China. There's no independent section for higher education according to its particularity, nor the social groups and employers emphasized in the supervision and management activities of higher education.

\section{B. Universities}

Peking University and the University of Hong Kong jointly launched Asian Campus Computing Survey in 2002. The main purpose of this project is to have a better understanding of the latest developments of information system in Asian universities, interact and learn from the successful experience in higher education informatization construction. Some key universities in China have also carried out researches related to information standards and technical specifications. For example, Zhejiang University and Xi'an Jiaotong University participated in the information system construction projects of educational services and supervision, which sponsored by the Computing Center of Tsinghua University,.

At the same time, colleges and universities also have launched online assessment systems, students and teachers are encouraged to make quality assessments of the education and teaching. For example, the Teaching Quality Assessment System of Tsinghua University is a five-dimensional assessment system comprised of experts focused assessment, cadres sampling assessment, teaching survey, instructor selfassessment and survey of graduates. The objective of the teaching quality assessment is to support the development of teaching, so that teachers and students would benefit from the assessment.

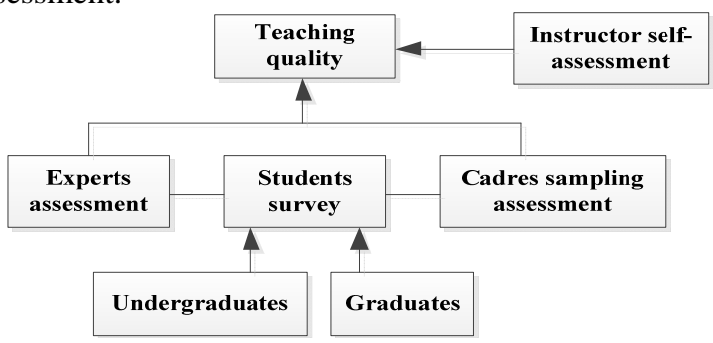

Figure 1. The five-dimensional teaching quality evaluation system of Tsinghua University
Tsinghua University has implemented the online assessment since 2004. Each semester there should be the evaluation of all teachers' teaching quality, providing a lot of valuable information for how to improve and enhance the quality of teaching. From the graduates of 2008, Tsinghua University has applied the online graduates in questionnaire surveys with a participating rate of $95 \%$. Because of the objectivity and integrity and as a supplement for the teaching quality assessment of each semester, the online graduate survey helps a lot for the school to have a better knowledge of students' attitudes and recommendations towards the educational reform and improvement direction. The statistical analysis of the online teaching evaluation has become the fundamental data for the teaching quality monitoring activities, providing important information and scientific decision-making basis for the management of education quality.

\section{HIGHER EDUCATION QUALITY SUPERVISION INFORMATION PLATFORM ANALYSIS}

Supervision work should pay attention to the characteristics of the regulatory object. The government should master the specific implementation details of quality management for higher education, which means that only the whole process multi-mode supervision can help to achieve the anticipant effect. On the other hand, universities will be faced with the problem of how to meet with the government's regulations without interfering the normal internal management. To construct the supervision information platform of higher education quality, we must primarily confirm the supervision contents and the supervising subjects.

\section{A. Supervision Cntents}

Under the guiding ideology of Opinions to Comprehensively Improve the Quality of Higher Education and combining the national conditions, this article has laid out the work breakdown structure of the supervision information platform for higher education, with a view to monitoring the higher education quality informationized supervision activities throughout the whole talent cultivation process and constituting a constantly adjusting main line, as shown in Figure 2.

The content of higher education quality includes not only basic elements as people, environment, work, risk, and management, but also management elements like culture, behavior, information and so on. In this WBS, supervision to practice \entreprise plan in the personal training program will motivate universities to strengthen the experimental teaching and entrepreneurship education, in order to promote the overall development of students; political course supervision is included to meet the demand to strengthen ideological and political education; teaching quality evaluation process, integration of the views of students and teachers, directly reflects the quality of classroom teaching and college management; what's more, this paper present employer as an important after evaluation subject, whose opinion reflects the social demand for talent to some extent. 


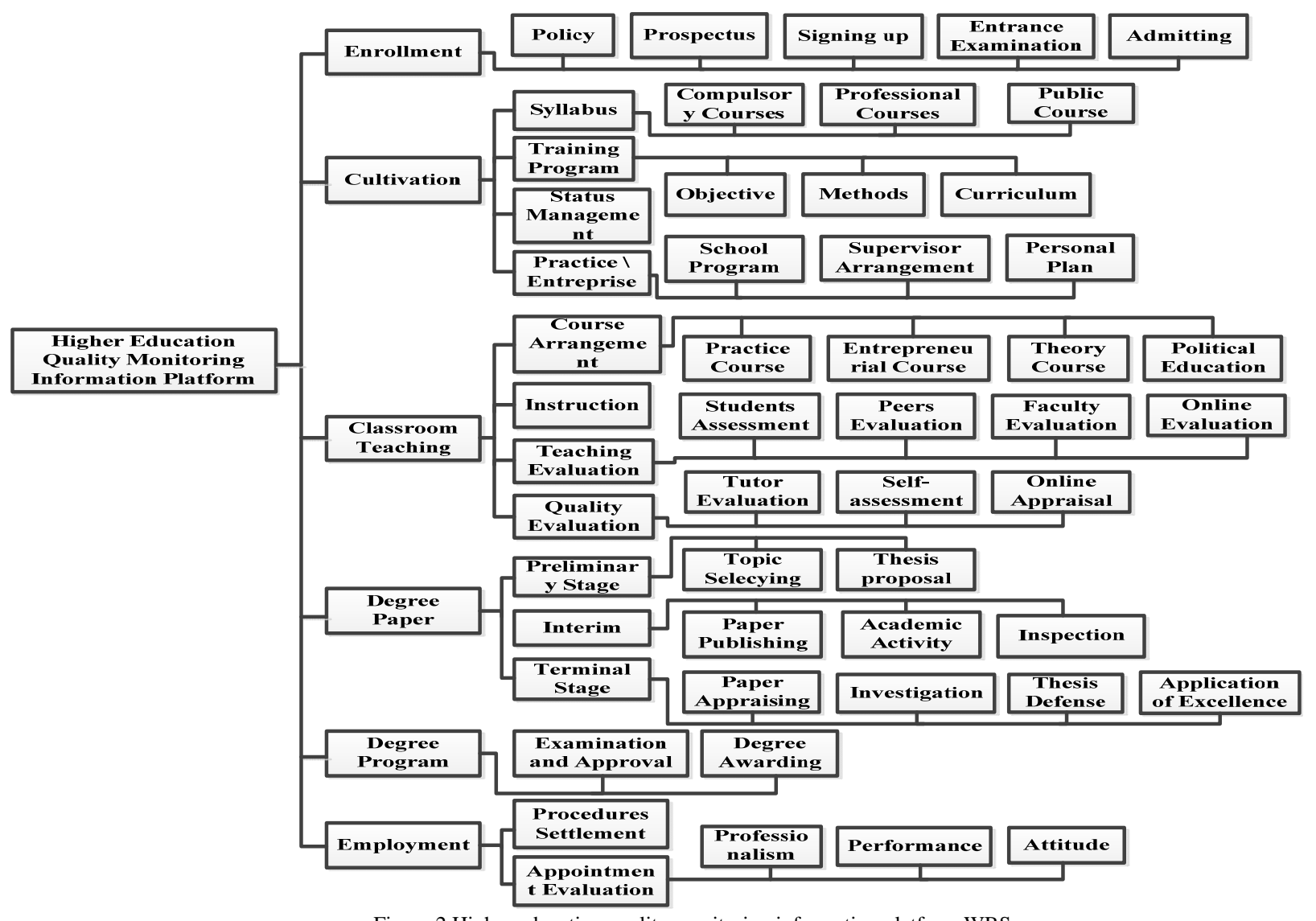

Figure 2.Higher education quality monitoring information platform WBS

\section{B. Supervising Sujects}

To construct the information platform for higher education quality supervision, we should first create synergetic supervision system. Supervising subjects in the system includes government, society and employer. Government departments as the Ministry of Education, the Ministry of Finance, and the Academic Degree Office of State Council should co-supervise the education quality activities. Led by the Ministry of Education, the government departments' comprehensive evaluation based supervision work should combine campus survey with data analysis and social feedback. As to the social level, parents and media should get access to the whole quality supervision process of higher education. The appeared or potential quality problems could be proposed or questioned by the information platform to promote higher education quality improvement. When it comes to the employer level, the university cooperated or authorized enterprise should make evaluation of the graduates' performance, which would be timely fed back to the information supervision platform to evaluate colleges' training program and the improvement of educational practice to meet the needs of society.

The horizontal quality supervision of higher education should cover the whole process of personnel training, following the implementation steps of the personnel training plan. Participants should not only clear their regulatory responsibilities, but also minimize unnecessary and overlapped regulatory work, ensuring the realization of the talent cultivation goals.

\section{COMPREHENSIVIE EVALUATION OF THE HIGHER EDUCATION SUPERVISION SYSTEM}

There is still a big gap in the information platform construction work of supervising the higher education quality in China presently. On the one hand, the construction work has not aroused enough attention by now; on the other hand, the supervising subjects' function has been out of balance and relatively independent during the supervision work. Therefore, in order to ensure the smooth construction of the informationized quality supervision platform of higher education, the supervising subjects should play their role to contribute to the collaborative supervision system, clearing supervision contents, implementing supervision activities , aggrandizing regulatory evaluation, and completing the supervision feedback. As shown in Figure 3.

\section{CONCLUSION}

With the development of information technology and the widespread concern of improving the quality of higher education, the construction of collaborative supervision information platform of higher education quality has been 
steadily embarked on a new level. However, in order to obtain a significant achievement, there need more supports from the government, as well as the wisdom of scientists. On the basis of summarizing the status of the supervision of higher education, this paper puts forward some suggestions on improving the construction of higher education collaborative supervision information platform, and clears the key points of quality supervision. The inadequacy of this paper is that there's no discussion of the specific embodiment of the information platform construction, further researches are needed to inject more momentum for the continuous development of Chinese higher education career.

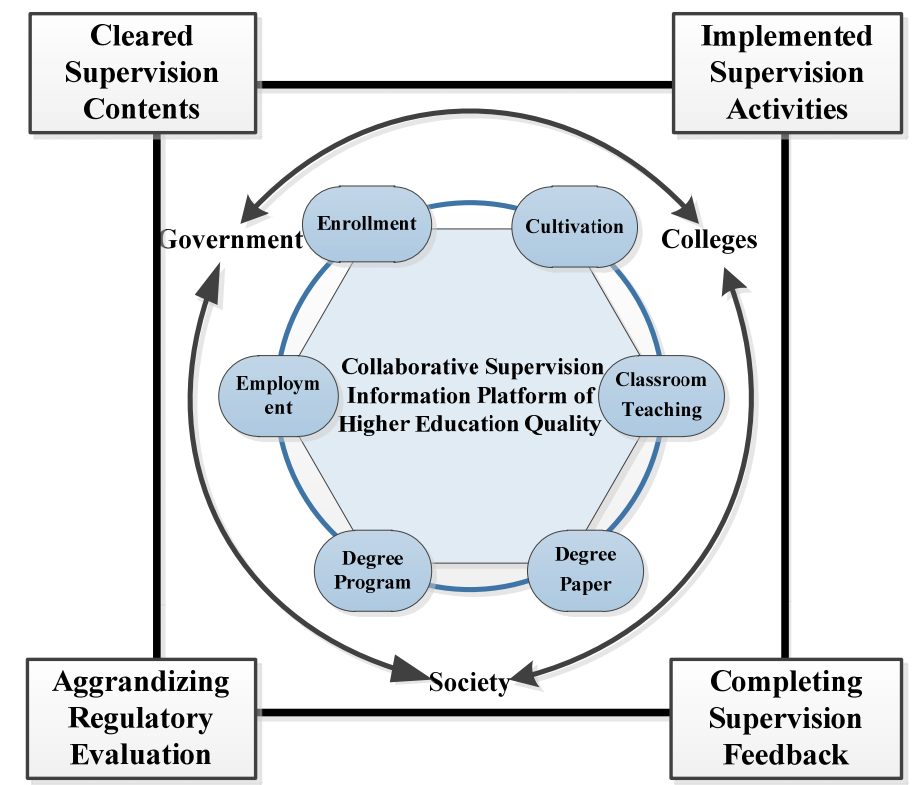

Figure 3.The collaborative supervision information platform of higher education quality

\section{ACKNOWLEDGMENT}

This work was financially supported by the Chinese National Nature Science Foundation of China (No. 71271085), Beijing Twelfth Five Year Plan Project of philosophy and social sciences (No. 12JGB044) and Beijing Municipal Commission of Education for joint projects with North China Electric Power University of 2012.

\section{REFERENCES}

[1] WU Jian-ping, YE Fu-gui, et al. China Higher Education Quality Management Study under the Popular Background[M]. Beijing: Tsinghua University Press, 2011: 125-126.

[2] WANG Jian-hua. Multi-viewed Higher Education Quality Management[M]. Guangdong Higher Education Press,2010
[3] [ZHANG Xu-sheng, WU Meng-ling. Thinking of the Higher Education Management Informationized Construction[J]. Computer \& Communication, 2011, (5): 207 - 209.

[4] ZHOU Chuan. Higher Education Management System Policy Analysis[J]. Journal of Higher Education, 2009, 30 (8): 51 - 54.

[5] WU Shun-bi. Review and Prospects of Information Technology in Higher Education in the New Century[J]. Education Exploration, 2011,240 (6): 135 - 137.

[6] NAN Xu-guang, LUO Hui-ying. Incentive Regulation Theory and Supervision Arrangements for Education[J]. The Contemporary Education Science, 2006, (23): 19 - 21.

[7] HA Xian-li. Higher Education Quality Monitoring Status and Monitoring System Construction Research [D]. Southwest University.2011. 